\title{
The Composition of Blended Learning Model and Its Application in English Classroom Teaching
}

\author{
Shuang Wang ${ }^{1, a^{*}}$ \\ ${ }^{1}$ Foreign Language Department, Qiqihar Medical University, Qiqihar, Heilongjiang, 161006 \\ a1652429272@qq.com \\ * the corresponding author
}

\section{Keyword: Blended learning model; Composition; English; Classroom teaching; Application}

\begin{abstract}
With the development of network information technology, people's cognitive ideas are changing constantly. The traditional teaching ideas and traditional teaching methods have been unable to meet the actual needs of teaching. The mixed teaching model provides a new way for the reform of education and teaching, in the teaching form will be combined with the traditional teaching and network teaching without time and space limit, through video, audio, text, graphics, animation and other multimedia technology, give full play to the leading role of teachers and students' subject status in teaching in English teaching, can expect to get better application effect. Combined with the development of modern information technology, the actual teaching tasks can be completed, and the mixed teaching mode can be used to promote the effectiveness of classroom teaching in high schools. This paper gives a brief introduction to the composition of blended learning model, and then focuses on its application in English classroom teaching.
\end{abstract}

\section{Introduction}

The concept of blended learning was first proposed by foreign training institutions. By introducing the combination of online and offline, and combining face-to-face teaching, the shortcomings of traditional teaching and E-Learning were improved. Subsequently, the blended learning model received great attention in the field of education.

\section{The Composition of Blended Learning Model}

Professor He Kekang of Beijing Normal University argues that the so-called "domestic hybrid learning is to take advantage of the traditional ways of learning and digital or network learning to combine the advantages of both to guide and inspire teachers to play a leading role, monitoring the teaching process, but also fully reflect the students as the main learning process of the initiative, enthusiasm and creativity". Shanghai Normal University Professor Li Jiahou that "blended learning" or "blended learning", is through the rational use of teachers and students in the process of teaching practice of the teaching media, teaching methods, teaching strategies and optimization, to optimize the teaching, promote students' learning purpose. South China Normal University professor Li Kedong believes that: hybrid learning can be seen as facing the organic integration of the classroom learning and online learning, its core idea is by starting to seek ideas and ways to solve the problem. At present, the consensus of the international educational technology community is that only by combining face-to-face learning with online learning, can the two sides complement each other in order to achieve the best learning results. Hybrid teaching mode of rapid development of computer technology, artificial intelligence and the theory of blended learning based on constructivist learning theory, socio-cultural learning theory formed by combining, attracted more and more attention at home and abroad. The president of the University of Pennsylvania suggests that the integration of online learning with classroom instruction, namely blended learning, is the most important trend in higher education. Simple classroom instruction and individual learning on the Internet can not achieve the desired results. Hybrid teaching mode is to optimize the integration of modern network technology and resources, autonomous learning mode and integration of 
personalized, using a flipped classroom model to fully mobilize the participation of students, enthusiasm, new teaching mode and teaching with students as the center.

The concept of blended instruction was first thought to introduce computers and the Internet into classroom instruction. And now has evolved into a huge educational projects, including in the traditional classroom teaching as a guide, and use a variety of technical means (such as electronic whiteboard, computer equipment, multimedia tools, electronic textbooks and online teaching plan etc.).

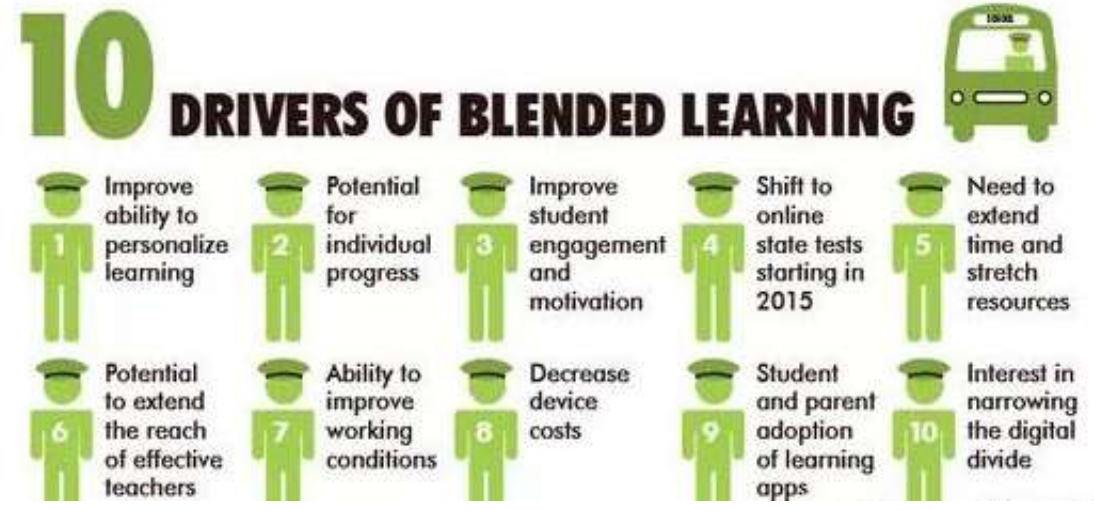

Figure 1. Composition of Blended Learning Model

\section{The Application of Blended Learning Model in English Classroom Teaching}

The blended learning model of College English is characterized by individuality, autonomy, inspiration and guidance. Hybrid teaching model one of the module is independent learning, this personalized and independent learning model advocated by the concept of lifelong learning, which make learning become a part of life, especially in foreign language learning. Therefore, according to the individual characteristics and differences of students, customized independent learning can be customized so that students can think more deeply, find problems and explore problems. In the classroom teaching, the teacher's inspiration and guidance teaching will promote the extension of independent learning in the classroom, that is, teachers can answer questions for students and lead the way, so that students can learn the language with half the effort. In interviews with students, it is understood that the majority of students recognize the blended learning model, which is beneficial to personal development and is beneficial to the improvement of language application ability and learning ability. However, there are also a few students who believe that the blended learning model is weak in monitoring, and if students are not strong self-discipline, it will lead to slow progress and low efficiency.

The Application of Reading Teaching in Blended Learning Model. The methods of College English reading teaching can be divided into intensive reading and extensive reading. There are two purposes of reading. One is to read for pleasure, and the other to read for information. If the decomposition of reading ability index, we will find that reading on language ability is comprehensive and complex, such as grammar (inflection, word patterns, vocabulary, language, social linguistics (mechanism) the ability to understand the connotation from the angle of social and cultural), (for the cohesion and discourse competence the structure of the understanding and ability of reading strategies).

In order to develop the reading ability as much as possible, we also adopt the blended learning model. From the classroom teaching, teachers' reading ability training is the first let the students grasp the background knowledge, let students enter the reading context; and then develop their lexical competence in the process of reading (vocabulary learning should not be isolated, the isolation outside the context, but should be imperceptibly influence in the context of enlightening). To ask questions and to teach students how to understand the article; then put forward the request to the reading speed, and the implementation of reading strategies in the reading practice; finally by the teacher evaluation progress of students. It can be said that the whole process of reading teaching is closely linked, full of thinking and imagination, so that students can enhance their ability in reading and achieve the purpose of language training. 
In a lot of Extracurricular Autonomous Learning, extracurricular reading at the same time to encourage students to arrange the students to read the feedback and report to read, reading into after-school clubs, training students' thinking of reading, to cultivate students' innovation spirit, the spirit of criticism.

The Application of Listening Teaching in Blended Learning Model. Listening ability has always been the bottleneck of language ability improvement in language learning. First of all, according to the requirements of College English teaching, we roughly divided the listening purposes into four categories: to understand the main idea, to understand specific information, to understand the details and to infer the implied meaning of words. Instant listening, speaking of the uncertainty, and the fragment in oral hesitant repetition and interrupted, can cause hearing as a difficulty of language learning, especially for the comparison of visualization and controllability of strong reading training. In the teaching of College English listening hybrid teaching model, we select and design and the actual life of college students is closer to the topic of classroom training, for example, news and hot research, contemporary Anglo American drama, the campus of the University of the real scene of dialogue and English songs etc.. In the process of language input, teachers focus on developing students' ability of taking notes, reporting and interpreting the original text and dictation ability. For example, in the ability to take notes, according to the specific listening materials, training students to sign symbols, records, key words, or master the drawing form, underline and so on. Dictation Training is the most basic listening is one of the most effective training methods, it requires the students to understand the purpose of the article is divided again, meaning group; second times according to the key words meaning group and let students dictation text; third times is to check and feedback. The blended learning model of listening is mainly embodied in the design of students' listening activities after class, which can give students a specific and practical task, and encourage students to study autonomously. For example, writing style and features on the listening material, to act out the dialogue in the listening material; oral abstract description of listening materials in news, interviews, or science stories; group discussion of personal hearing feedback; discourse analysis in listening text, learning grammar, vocabulary and writing style from it; or put the listening text cloze training for autonomous learning more direction of students' listening training.

The Application of Writing (Translation) Teaching in Blended Learning Model. Writing is not the end of language learning, but a way to learn language content and culture. Reading and writing can promote each other, mutual influence: reading writing language input can be accumulated, writing can also promote reading and thinking, the deeper the most effective way to improve the writing ability of reading is the input training a large number. The process of college students English writing is the generation of exploratory, the writer is trying to find and rebuild their own ideas, for the most close to the second language to describe his inner thoughts and feelings, so the writing process should be one of the most complicated cognitive process. In the classroom teaching of College English writing, teachers should pay attention to lead students to have three dimensions of thinking: first, to inspire the author to review the background knowledge of the writing subject, and to draw up the writing plan. The two is to guide students to determine the structure and ideas of the article, to set the goal of writing, and then to write translation (translate thinking into language).After the modification, polishing and editing, there should also be teacher intervention and guidance. The third dimension is to construct a reasonable writing task module and create a writing task environment. For the evaluation of writing task modules and the construction of environment, peer correction and teacher guidance can be adopted. In reading teaching, the integration of writing task teaching is an important aspect of the exploration of writing class teaching

The Application of Oral English Teaching in Blended Learning Model. The communicative nature of language determines that spoken language teaching is an essential part of language acquisition. The subject is divided into two parts: subject and module. The mixed teaching model is adopted to carry out the oral English Teaching Arrangement of practical spoken English autonomous learning tasks. The oral English training in pronunciation, intonation, speed and pitch is the most basic, the design of classroom activities will be more diverse, such as dialogue, voice exercises, simulation based on My ETS computer system, but also including speaking and writing tasks, performing tasks such as drama group. In the classroom, teachers consciously participate in the training of students, to students' oral tasks from productive, objective, communicative, challenging, pure accent of several aspects such as guidance, assessment and evaluation. The teacher's active 
participation will enable students to increase their expressiveness, enhance their sense of participation and accomplish their oral tasks better. The two language acquisition theory emphasizes the input output hypothesis of language. Based on this theory, the generation of language will be based on a large amount of material and data input, and so is spoken language. In the hybrid teaching mode in oral, students autonomous learning in oral English teachers, as the input link, will recommend the correction software, voice dubbing module, Listening immersion training, live show and common chat show video for students to watch. The teacher set the oral English teaching activities must let students feel is a learning experience, stimulate students' oral English training enthusiasm, training students to understand the language of the specific structure, master corresponding skills, but also can detect the accuracy of students' oral expression and the expression of logical integrity.

\section{Summary}

The research shows that the students are satisfied with the effect of the blended learning model, and show great concern about the teaching design, teacher-student interaction and self-regulated learning module in the flipped classroom and blended learning model. Therefore, the blended learning model can optimize the classroom teaching, help to realize the student centered teaching idea, and improve the students' practical English ability and independent learning ability. Hybrid teaching model applied in the field of language teaching, more emphasis on cultivating students' ability of language application, it uses task type, cooperation type, project type, inquiry teaching method, led by the teacher, the students as the main body of the teaching activities from "teaching" to "learning" change, make the teaching process implementation change attention from "teaching objectives" to focus attention on "learning needs", and has formed by teachers, to inspire and guide students to actively participate in the main features of the normal teaching. Hybrid teaching mode pays attention to students' potential, to provide students with lots of self exploration, discussion, questioning and criticizing the opportunity to help their innovative ideas in teamwork, test the authenticity of theory in practice, and to explore the dialectical relationship between tradition and innovation. In addition, in a face-to-face classroom instruction, teachers can not only eliminating confusion, but also can attract students' innovative thinking, obviously, this is a teaching mode of brave innovation, innovation is an education in science and technology.

\section{Acknowledgements}

Fund Project: The Teaching Research Project of Qiqihar Medical University in 2017 Titled "The Research on the Degree of University Students' Participation in English Learning under the Blended Learning Model" (Grant No. QYJY20170107) .

\section{References}

[1] Dominika Goltz-Wasiucionek. The use of blended learning and its influence on the assessment of motivating factors to learn English[J].International journal of continuing engineering education and life-long learning,2014,24(1):107-118.

[2] Jiyou Jia, Yuhao Chen, Zhuhui Ding et al. Effects of a vocabulary acquisition and assessment system on students' performance in a blended learning class for English subject[J]. Computers \&amp; education, 2012,58(1):63-76.

[3] Ya-Ting Carolyn Yang, Ya-Chin Chuang, Lung-Yu Li et al. A blended learning environment for individualized English listening and speaking integrating critical thinking[J].Computers \&amp; education,2013,63(Apr.):285-305.

[4] Nicholas Ferriman. The impact of blended e-learning on undergraduate academic essay writing in English (L2)[J].Computers \&amp; education,2013,60(1):243-253. 
[5] Liu Siyang.Web2.0-based Blended Learning in College English Teaching[C].//2013 International conference on information, business and education technology: ICIBET 2013, Beijing, China, 14-15 March 2013, volume 1 of 2.2013:643-646. 